KONSTRUKTIVISME, Vol. 10, No. 1, Januari 2018

p-ISSN: 1979-9438; e-ISSN: 2442-2355

FKIP Universitas Islam Balitar, Blitar

Http://konstruktivisme.unisbablitar.ejournal.web.id; Email: konunisba@gmail.com

\title{
PENERAPAN METODE PRAKTIKUM PEMBUATAN NATA DE MILK PADA MATAKULIAH PENGANTAR BIOTEKNOLOGI DI PROGRAM STUDI PENDIDIKAN BIOLOGI UNIVERSITAS ISLAM BALITAR BLITAR
}

\author{
Dian Puspita Anggraini (1), Eva Nurul Malahayati (2) \\ Prodi Pendidikan Biologi FKIP Universitas Islam Balitar Blitar \\ Jl. Majapahit No. 04 Blitar \\ E-mail : dpuspita4@gmail.com
}

\section{ABSTRAK}

Pembelajaran bioteknologi dituntut untuk menerapkan pembelajaran yang melibatkan mahasiswa dalam proses pembelajaran. Salah satu metode pembelajaran yang dapat diterapkan adalah penerapan metode praktikum pembuatan nata de milk. Penerapan metode ini melibatkan mahasiswa dalam berbagai aktivitas belajar dan mengembangkan sejumlah keterampilan proses sains. Tujuan penelitian ini adalah untuk mengetahui hasil penerapan metode praktikum pembuatan nata de milkterhadap keterampilan proses sains dan hasil belajar.

Penelitian ini dilaksanakan di laboratorium Biologi Universitas Islam Balitar Blitar Tahun Akademik2016/2017. Populasi dalam penelitian ini adalah seluruh mahasiswa program studi pendidikan biologi, adapun sampelnya adalah mahasiswa biologi semester 6.Rancangan penelitiannya adalah Pre Experimental Design dengan jenis One Shoot Case Study.

Hasil penelitian menunjukkan bahwa penilaian keterampilan proses sains pada mahasiswa biologi semester 6 menunjukkan bahwa seluruh siswa mencapai keterampilan proses sains dengan kriteria baik dan baik sekali. Hal ini menunjukkan bahwa keterampilan proses sains telah mencapai indikator keberhasilan yaitu $\geq 75 \%$ mahasiswa mempunyai keterampilan proses sains dengan kriteria baik. Hasil belajar mahasiswa $\geq 85 \%$ telah mencapai nilai 80 .

Berdasarkan hasil penelitian dapat disimpulkan bahwa pembelajaran dengan metode praktikum pembuatan nata de milk dapat diterapkan pada matakuliah pengantar bioteknologi yang ditunjukkan dengan tercapainya indikator keberhasilan 
Dian Puspita Anggraini (1), Eva Nurul Malahayati (2). 2018. Penerapan Metode Praktikum Pembuatan Nata de Milk Pada Matakuliah Pengantar Bioteknologi di Program Studi Pendidikan Biologi Universitas Islam Balitar. Konstruktivisme, 10 (1): 1-16

yaitu $\geq 75 \%$ mahasiswa mempunyai keterampilan proses sains dengan kriteria baik dan $\geq 85 \%$ mahasiswa memperoleh nilai hasil belajar $\geq 80$. Saran yang dapat disampaikan peneliti yaitu metode praktikum pembuatan nata de milkperlu dikembangkan pada konsep lain yang memiliki permasalahan yang sama.

Kata Kunci: praktikum, Nata de Milk, Bioteknologi

\section{ABSTRACT}

Biotechnology learning was required to apply learning that involving students in the learning process. One of the learning method that can be applied was the implementation of making Nata de Milk. The implementation of this method involving students in various learning activities and develop a number of science process skills. The aim of this research was to determine the result of implementation in practice method of making Nata de Milk on science process skills and learning achievement.

This research was conducted in the Biology laboratory at Islamic University of Balitar in the 2016-2017 Academic Year. The population in this research were all of the students in the biology education study program, and as for the sample was biology students at the sixth semester of. The research method was Pre Experimental Design with the type of One Shoot - Case Study.

The result of this research showed that the assessment of science process skills of biology students in the sixth semester indicates that all of the students achieved science process skills with good and excellent criteria. It showed that the science process skills has reached the indicator of success $\geq 75 \%$ students get the science process skills with good criteria. The students achievement $\geq 85 \%$ has reached 80.

Based on those results, it can be concluded that the learning process using practice method of making Nata de Milk can be applied to the introductory course of biotechnology, shown by the achievement of the indicator of success that is $\geq 75 \%$ of students have the science process skills with good criteria and $\geq 85 \%$ of students get the value of learning achievement about $\geq 80$. The suggestions that can be submitted by researchers was the practice method of making Nata de Milk needs to be developed on the other concept which have the same problem.

Keywords: Practice, Nata de Milk, Biotechnology. 
Dian Puspita Anggraini (1), Eva Nurul Malahayati (2). 2018. Penerapan Metode Praktikum Pembuatan Nata de Milk Pada Matakuliah Pengantar Bioteknologi di Program Studi Pendidikan Biologi Universitas Islam Balitar.

Konstruktivisme, 10 (1): 1-16

\section{PENDAHULUAN}

Sains berkaitan dengan cara mencari tahu (inquiry) tentang alam secara sistematis, sehingga pendidikan sains bukan hanya sebagai penguasaan kumpulan pengetahuan yang berupa fakta-fakta, konsep-konsep atau prinsip-prinsip saja, tetapi juga merupakan suatu proses penemuan.. Karakteristik dari sains antara lain lain adalah bersifat abstrak, konsep-konsep yang disederhanakan dari yang sebenanya serta konsep-konsep yang saling berkaitan dan berurutan. Proses pembelajaran sains perlu menekankan pada pemberian pengalaman langsung. Pembelajaran yang melibatkan siswa secara langsung akan menghasilkan pembelajaran yang efektif dan mencapai tujuan pembelajaran. Edgar Dale (dalam Sanjaya, 2007) menyatakan bahwa pengetahuan itu dapat diperoleh melalui pengalaman langsung. Semakin langsung objek yang dipelajari, maka semakin kongkrit pengetahuan yang diperoleh siswa. Sebaliknya, semakin tidak langsung pengetahuan itu diperoleh maka semakin abstrak pengetahuan siswa.

Biologi sebagai salah satu bidang sains menyediakan berbagai pengalaman belajar untuk memahami konsep dan proses sains.Keterampilan proses sains pada pembelajaran sains lebih menekankan pembentukan keterampilan untuk memperoleh pengetahuan dan mengkomunikasikan hasilnya. Keterampilan proses sains dimaksudkan untuk mengembangkan kemampuan-kemampuan yang dimiliki oleh siswa. Ada berbagai keterampilan dalam keterampilan proses, keterampilan - keterampilan tersebut terdiri dari keterampilan-keterampilan dasar (basic skills) dan keterampilan-keterampilan terintegrasi (intregated skills). Keterampilan-keterampilan dasar terdiri dari enam keterampilan, yakni: mengobservasi, mengklasifikasi, memprediksi, mengukur, menyimpulkan, dan mengkomunikasikan. Sedangkan keterampilanketerampilan terintegrasi terdiri dari mengidentifikasi variabel, membuat tabulasi data, menyajikan data dalam bentuk grafik, menggambarkan hubungan antar variabel, mengumpulkan dan mengolah data, menganalisa penelitian, menyusun hipotesis,mendefinisikan variabel secara operasional, merancang penelitian, dan melaksanakan eksperimen (Funk, 1985 dalam Dimyati dan Mudjiono, 2002). Menurut Dimyati dan Mudjiono (2002) bahwa keenam aspek keterampilan proses sains dasar tersebut adalah: (1) mengamati, (2) mengklasifikasikan, (3) mengkomunikasikan, (4) mengukur, (5) memprediksi, (6) menyimpulkan. 
Dian Puspita Anggraini (1), Eva Nurul Malahayati (2). 2018. Penerapan Metode Praktikum Pembuatan Nata de Milk Pada Matakuliah Pengantar Bioteknologi di Program Studi Pendidikan Biologi Universitas Islam Balitar.

Konstruktivisme, 10 (1): 1-16

Keterampilan proses sains ini dapat diaplikasikan pada kegiatan praktikum.Kegiatan praktikum merupakan bagian yang tidak terpisahkan dalam pembelajaran IPA khususnya Biologi, sehingga IPA disebut dengan experimental science. Hal itu sejalan dengan pendapat Sagala (2005) yang menjelaskan bahwa proses belajar mengajar dengan praktikum ini berarti mahasiswa diberi kesempatan untuk mengalami sendiri, mengikuti proses, mengamati suatu objek, menganalisis, membuktikan, dan menarik kesimpulan sendiri tentang suatu objek, keadaan atau proses sesuatu. Lebih lanjut Subiantoro(2010) menyatakan bahwa di dalam kegiatan praktikum sangat dimungkinkan adanya penerapan beragam keterampilan proses sains sekaligus pengembangan sikap ilmiah yang mendukung proses perolehan pengetahuan (produk keilmuan) dalam diri mahasiswa. Kegiatan praktikum memiliki kedudukan yang amat penting dalam pembelajaran IPA, karena melalui praktikum siswa memiliki peluang mengembangkan dan menerapkan keterampilan proses sains, sikap ilmiah dalam rangka memperoleh pengetahuannya. Praktikum merupakan salah satu bentuk pengajaran yang efektif, karena sekaligus dapat melalui tiga ranah yaitu ranah afektif, kognitif, dan psikimotorik (Zainudin, 2001).

Hasil observasi awal pada kegiatan belajar mengajar matakuliah pengantar bioteknologi menunjukkan bahwa metode pembelajaran bioteknologi yang diterapkan adalah metode presentasi dan penugasan. Penggunaan metode presentasi membuat mahasiswa tidak mengalami secara langsung sehingga pengalaman belajar mahasiswa kurang. Pembelajaran yang kurang melibatkan partisipasi mahasiswa secara aktif berpotensi membosankan. Sedangkan metode penugasan membuat guru tidak bisa mengamati aktivitas siswa secara langsung karena hanya dinilai dari hasil laporan penugasan tersebut sehingga penilaian aktivitas siswa belum optimal.Selain itu, kegiatan pembuatan Nata de Milk belum pernah dilakukan selama pembelajaran bioteknologi. Hasil observasi terhadap fasilitas laboratorium di program studi Biologi FKIP UNISBA sudah cukup memadai untuk keperluan praktikum. Objek yang dikaji dalam proses pembuatan Nata de Milkadalah fenomena nyata yaitu pemanfaatan mikroorganisme dalam menghasilkan barang dan jasa yang lebih bernilai.

Proses pembuatan Nata de Milkdari limbah whey merupakan teknologi terapan yang diadopsi dari teknologi pembuatan nata de coco dengan mengganti air kelapa dengan whey sebagai media fermentasidengan menambahkan Acetobacter xylinum sebagai starter. Menurut Thiman (1962) 
Dian Puspita Anggraini (1), Eva Nurul Malahayati (2). 2018. Penerapan Metode Praktikum Pembuatan Nata de Milk Pada Matakuliah Pengantar Bioteknologi di Program Studi Pendidikan Biologi Universitas Islam Balitar.

Konstruktivisme, 10 (1): 1-16

dalam Palungkung (1993) pembentukan nata terjadi karena proses pengambilan glukosa dari larutan gula dan medium yang mengandung glukosa oleh sel-sel Acetobacter xylinum. Whey adalah serum susu yang dihasilkan dari industri pembuatan keju setelah proses pemisahan kasein dan lemak selama pengendapan susu. Setiap kilogram keju yang diproduksi menghasilkan 8-9 L whey (Jenie dan Rahayu, 1993).Kandungan gizi whey antara lain protein, gula susu (laktosa), mineral dan sejumlah kecil lemak. Whey mengandung banyak belerang dan asam amino esensial (Idris, 2003). Jenis protein yang terlarut dalam whey adalah $\alpha$-laktalbumin, $\beta$-laktoglobulin, immunoglobulin dan serum albumin (Widodo, 2003).

Proses pembuatan Nata de Milkmelalui lima tahap, yaitu tahap pertama dalam pembuatan nata adalah menyaring whey yang berasal dari limbah industri pengolahan susu dengan penyaring untuk menghilangkan kotoran dan gumpalan-gumpalan yang terdapat pada whey. Tahap kedua, kemudian whey yang telah disaring dipanaskan sambil diaduk-aduk sampai mendidih untuk mensterilkan media. Selanjutnya disebut media fermentasi. Tahap ketiga adalah pengkondisian media, dimana dalam tahap ini media fermentasi ditambah sukrosa, ammonium sulfat dan mengalami pengaturan $\mathrm{pH}$. Pengaturan $\mathrm{pH}$ pada media fermentasi dengan ditambah asam asetat glasial sekitar $25 \mathrm{ml}$ sampai $\mathrm{pH} \mathrm{4,0}$ dan diaduk hingga merata.Media fermentasi selanjutnya ditambah sukrosa $10 \%(\mathrm{~m} / \mathrm{v})$ dan ammonium sulfat $5 \mathrm{~g}$. Didihkan kembali sampaisuhu $100^{\circ} \mathrm{C}$ selama 10 menit. Setelah itu, media fermentasi dimasukkan kedalam baki steril berukuran $(34 \times 25 \times 5) \mathrm{cm}$ dan ditutup dengan kertas steril supaya media tidak terkontaminasi dengan lingkungan sekitar. Selanjutnya, media fermentasi didinginkan hingga suhunya berkisar antara 28$30^{\circ} \mathrm{C}$. Selanjutnya disebut media starter. Tahap keempat adalah penambahan starter (inokulasi) Acetobacter xylinum pada media starter. Starter nata $d$ diinokulasi secara aseptis ke dalam media dengan volume $10 \%(\mathrm{v} / \mathrm{v})$. Baki plastik tempat fermentasi setelah inokulasi starter nata kemudian ditutup kembali dengan kertas steril, diikat dengan tali karet dan diinkubasi pada suhu $28-30^{\circ} \mathrm{C}$. Tahap terakhir atau kelima dalam penelitian ini adalah proses fermentasi. Media fermentasi yang telah diinokulasi bakteri selanjutnya diinkubasi selama 10 hari. Nata dipanen dengan mengeluarkannya dari baki plastik, kemudian dibuang lapisan tipis di bagian bawahnya. Setelah dibersihkan nata kemudian direbus. Nata yang telah terbentuk selanjutnya direbus selama direbus selama 5 menit dengan tujuan menghentikan aktivias Acetobacter xylinum. Nata kemudian direndam selama 2 hari dengan menggati 
Dian Puspita Anggraini (1), Eva Nurul Malahayati (2). 2018. Penerapan Metode Praktikum Pembuatan Nata de Milk Pada Matakuliah Pengantar Bioteknologi di Program Studi Pendidikan Biologi Universitas Islam Balitar. Konstruktivisme, 10 (1): 1-16

air rendaman setiap hari untuk menghilangkan aroma asam. Nata tersebut direbus kembali selama 10 menit untuk siap dikonsumsi.

Pembelajaran dengan metode praktikum pembuatan Nata de Milk dipilih karena dianggap sesuai untuk menyampaikan materi fermentasi pada matakuliah pengantar bioteknologi karena pembelajaran dengan metode praktikum pembuatan Nata de Milkmahasiswa langsung dapat mengamati proses-proses fermentasi yang terjadi dalam bioteknologi. Pengalaman langsung merupakan pengalaman yang diperoleh siswa sebagai hasil dari aktivitas siswa sendiri. Siswa mengalami, merasakan sendiri segala sesuatu yang berhubungan dengan objek yang dipelajarinya. Siswa berhubungan langsung dengan objek yang hendak dipelajari tanpa menggunakan perantara. Karena pengalaman langsung inilah maka ada kecenderungan hasil yang diperoleh siswa menjadi kongkrit (Sanjaya 2007).Selain itu mahasiswa juga dapat menghasilkan produk bioteknologi yang dalam praktikum ini berupa Nata de Milk. Nata de Milkmerupakan salah satu produk bioteknologi yang dapat dibuat dengan mudah dan tidak memerlukan peralatan yang rumit.

\section{METODE}

Penelitian ini merupakan penelitian Pre Experimental Design, dengan jenis One Shoot - Case Study yang bertujuan untuk mengetahui hasil penerapan praktikum pembuatan Nata de Milk dari limbah whey dalam pembelajaran pengantar bioteknologi. Pola desain penelitian ini dapat dilihat pada Gambar 1.

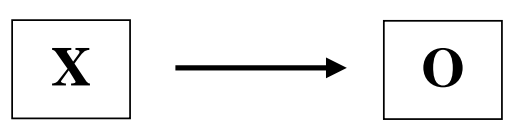

Gambar 1. Pola desain One Shoot-Case Study

Keterangan:

$X$ : Perlakuan dengan praktikum pembuatan Nata de Milk

$\mathrm{O}$ : Hasil observasi setelah perlakuan dengan praktikum pembuatan Nata de Milk 
Dian Puspita Anggraini (1), Eva Nurul Malahayati (2). 2018. Penerapan Metode Praktikum Pembuatan Nata de Milk Pada Matakuliah Pengantar Bioteknologi di Program Studi Pendidikan Biologi Universitas Islam Balitar.

Konstruktivisme, 10 (1): 1-16

Populasi pada penelitian ini adalah seluruh mahasiswa progarm studi Biologi FKIP Universitas Islam Balitar Blitar. Sampel penelitian adalah mahasiswa semester 6 yang berjumlah 27 mahasiswa. Pengambilan sampel pada penelitian ini dilakukan dengan menggunakan teknik Purposive Sampling.Purposive Sampling adalah teknik pengambilan subyek penelitian bukan didasarkan atas strata, random atau daerah tetapi didasarkan atas adanya tujuan tertentu (Arikunto 2006).

Faktor yang diteliti meliputi dosen dan mahasiswa. Pengamatan dosen dilakukan pada kinerja /performance dosen dalam kegiatan belajar mengajar meliputi langkah-langkah proses pembelajaran yang seharusnya dilakukan dosen secara keseluruhan. Sedangkan, pengamatan mahasiswa meliputi aktivitas mahasiswa dalam mengikuti proses pembelajaran dan menganalisis hasil belajar dengan indikator yang harus dikuasai mahasiswa setelah mengikuti proses pembelajaran. Selama penelitian ini, peneliti dibantu oleh 2 orang observer.

Prosedur penelitian dalam penelitian ini terdiri atas persiapan dan pelaksanaan penelitian. Pada tahap persiapan, dosen mempersiapkan perangkat pembelajaran (RPS dan RPPS) dan perangkat tes. Selanjutnya, pelaksanaan penelitian dilakukan selama 3 kali pertemuan. Pertemuan pertama, dosen memberikan pengantar tentang proses pembuatan nata dan membentuk kelompok. Kemudian, siswa ditugaskan untuk mempersiapkan limbah whey. Pada pertemuan kedua dilakukan proses pembuatan Natade Milk dari limbah whey olehmahasiswa secara berkelompok. Proses pembuatan Nata de Milkdengan melalui lima tahap, yaitu: penyaringan limbah, pemanasan limbah, pengkondisian media, inokulasi, dan fermentasi (inkubasi). Observer mengamati kinerja siswa selama kegiatan praktikum berlangsung. Pada pertemuan ketiga, mahasiswa melakukan pengamatan terhadap hasil praktikum pembuatan Nata de Milkdan menghimpun data praktikum. Pada pertemuan selanjutnya dilakukan evaluasidan siswa mengumpulkan tugas laporan membuat Nata de Milk.

Data yang diperoleh meliputi keterampilan proses sains dan hasil belajar mahasiswa. Selanjutnya data dianalisis dengan rumus deskriptif menggunakan rating scale, pada setiap item performance diberi skala penilaian $1 \mathrm{~s} / \mathrm{d} 4$. Kemudian skor yang diperoleh dijumlahkan dan diubah menjadi nilai huruf dengan konversi skala 5. Penentuan konversi skala 5 dapat dilihat pada Tabel 1. 
Dian Puspita Anggraini (1), Eva Nurul Malahayati (2). 2018. Penerapan Metode Praktikum Pembuatan Nata de Milk Pada Matakuliah Pengantar Bioteknologi di Program Studi Pendidikan Biologi Universitas Islam Balitar. Konstruktivisme, 10 (1): 1-16

Tabel 1. Konversi skala 5

\begin{tabular}{cccccc}
\hline No & $\begin{array}{c}\text { Tingkat } \\
\text { Penguasaan }\end{array}$ & $\begin{array}{c}\text { Batas } \\
\text { Atas }\end{array}$ & $\begin{array}{c}\text { Batas } \\
\text { Bawah }\end{array}$ & Nilai & Kriteria \\
\hline 1 & $85-100$ & $100 \% \times S M I$ & $85 \% \times S M I$ & A & Baik sekali \\
\hline 2 & $70-84$ & $84 \% \times$ SMI & $70 \% \times S M I$ & B & Baik \\
\hline 3 & $60-69$ & $69 \% \times S M I$ & $60 \% \times S M I$ & C & Cukup \\
\hline 4 & $50-59$ & $59 \% \times$ SMI & $50 \% \times S M I$ & D & Kurang \\
\hline 5 & $>50$ & $50 \% \times S M I$ & $>50 \% \times S M I$ & E & Sangat kurang \\
\hline
\end{tabular}

Data hasil belajar mahasiswa dianalisis dengan cara:

a. Menghitung skor evaluasi akhir yang diperoleh dalam lembar penskoran evaluasi akhir

b. Menghitung tingkat penguasaan evaluasi akhir =

Jumlah skor hasil evaluasix $100 \%$ (Arikunto, 2006)

Skor maksimum ideal

c. Menghitung skor mahasiswa dalam penyusunan laporan hasil proyek eksperimen pembuatan Nata de Milk.

d. Menghitung tingkat penguasaan laporan

e. Menghitung hasil belajar mahasiswa yang berupa nilai akhir dengan menggunakan rumus sebagai berikut.

$$
\mathrm{NA}=\frac{2 \mathrm{~A}+\mathrm{B}}{3} \times 100 \%
$$

Keterangan:
A : ulangan harian atau post tes
B : laporan hasil praktikum

f. Menentukan batas kelulusan individu yaitu hasil belajar.

\section{HASIL DAN BAHASAN}

Hasil penelitian ini meliputi keterampilan proses sains dan hasil belajar sebagai data utama. Sedangkan kinerja dosen dan tanggapan mahasiswasebagai data pendukung. Data hasil penelitian yang lebih rinci dijelaskan sebagai berikut.

\section{Keterampilan Proses Sains}

Keterampilan proses sains mahasiswa yang dinilai dalam praktikum ini adalah keterampilan menggunakan alat dan melakukan kerja saat praktikum, 
Dian Puspita Anggraini (1), Eva Nurul Malahayati (2). 2018. Penerapan Metode Praktikum Pembuatan Nata de Milk Pada Matakuliah Pengantar Bioteknologi di Program Studi Pendidikan Biologi Universitas Islam Balitar.

Konstruktivisme, 10 (1): 1-16

menyusun hipotesis, mengamati hasil perlakuan, mengukur hasil praktikum, menghimpun data percobaan, mengkomunikasikan hasil praktikum, membuat kesimpulan, dan menyusun laporan. Data tentang keterampilan proses sains mahasiswa dapat dilihat pada Tabel 2.

Tabel 2. Tabel Aspek Keterampilan Proses Sains

\begin{tabular}{clc}
\hline No. & \multicolumn{1}{|c}{ Parameter Aktivitas } & $\begin{array}{c}\text { Skor Per } \\
\text { Aspek }\end{array}$ \\
\hline 1 & Menggunakan alat dan melakukan kerja & 3.92 \\
\hline 2 & Mengamati hasil perlakuan & 3.98 \\
\hline 3 & Mengukur hasil praktikum & 3.73 \\
\hline 4 & Menyampaikan hasil praktikum & 3.82 \\
\hline 5 & Menyusun hipotesis & 3.56 \\
\hline 6 & Menghimpun data percobaan & 3.78 \\
\hline 7 & Membuat kesimpulan & 3.46 \\
\hline 8 & Menyusun laporan & 3.75 \\
\hline
\end{tabular}

Berdasarkan Tabel 2 dapat diketahui bahwa skor rata-rata pada aspek menggunakan alat dan melakukan kerja yaitu 3,92 menunjukkan bahwa mahasiswa dapat melakukan kerja dengan urut sesuai petunjuk dan dapat menggunakan alat-alat laboratorium. Skor rata-rata aspek mengamati hasil perlakuan yaitu 3,98 menunjukkan bahwa mahasiswa mampu melakukan pengamatan dan membuat perbandingandengan produk sebelumnya. Skor aspek mengukur hasil praktikum yaitu 3,73 menunjukkan bahwa mahasiswa dapat mengukur ketebalan nata dengan teliti, sungguh-sungguh dan benar sesuai dengan objek yang diukur. Skor aspek menyampaikan hasil praktikum adalah 3,82 menunjukkan bahwa mahasiswa dapat menyampaikan hasil praktikum dengan benardan mampu menggambarkan tabel atau grafik dengan jelas serta dapat menjelaskannya. Skor aspek menyusunhipotesis yaitu 3,56 menunjukkan bahwa mahasiswa mampu menyusun hipotesis dengan benar. Skor rata-rata aspek menghimpun data percobaan yaitu 3,78 menunjukkan bahwa siswa dapat menghimpun data percobaan dengan membuat tabel, ditulis dengan rapi, tulisan jelas, dan data ditulis sesuai dengan fakta. Skor aspek membuat kesimpulan yaitu 3,46 menunjukkan bahwa siswa dapat membuat kesimpulan dengan benar namun masih menggunkan kalimat yang bertele-tele. Skor aspek menyusun laporan yaitu 3,75 menunjukka bahwa siswa dapat 
Dian Puspita Anggraini (1), Eva Nurul Malahayati (2). 2018. Penerapan Metode Praktikum Pembuatan Nata de Milk Pada Matakuliah Pengantar Bioteknologi di Program Studi Pendidikan Biologi Universitas Islam Balitar.

Konstruktivisme, 10 (1): 1-16

menyusun laporan sesuai petunjuk penulisan laporan (sistematis) dengan cukup lengkap.

Tabel 3 Data Hasil Keterampilan Proses Sains

\begin{tabular}{ccccc}
\hline No & Nilai & Kriteria & $\begin{array}{c}\text { Jumlah } \\
\text { Mahasiswa }\end{array}$ & Persentase \\
\hline 1 & $85-100$ & Baik sekali & 20 & $74.07 \%$ \\
\hline 2 & $70-84$ & Baik & 7 & $25.93 \%$ \\
\hline 3 & $60-69$ & Cukup & 0 & $0 \%$ \\
\hline 4 & $50-59$ & Kurang & 0 & $0 \%$ \\
\hline 5 & $>50$ & Sangat kurang & 0 & $0 \%$ \\
\hline
\end{tabular}

Berdasarkan Tabel 3 dapat diketahui bahwa penilaian keterampilan proses sains secara klasikal mencapai indikator keberhasilan yaitu sebesar $\geq$ $75 \%$. Hasil observasi keterampilan proses sains dalam praktikum pembelajaran materi fermentasi seluruh mahasiswa mencapai kriteria baik dan baik sekali.

Keterampilan proses adalah keterampilan yang diperoleh dari latihan kemampuan-kemampuan mental, fisik, dan sosial yang mendasar sebagai penggerak kemampuan-kemampuan yang lebih tinggi. Kemampuankemampuan mendasar yang telah dikembangkan dan telah terlatih lamakelamaan akan menjadi suatu keterampilan (Hariwibowo, dkk., 2009). Keterampilan proses sains yang dinilai dalam penelitian ini yaitu keterampilan menggunakan alat dan melakukan kerja, mengamati hasil praktikummengukur hasil praktikum, mengkomunikasikan hasil praktikum dengan lisan, menyusun hipotesis, menghimpun data, membuat kesimpulan, dan menyusun laporan. Dari kedelapan aspek tersebut mahasiswa sudah melakukannya dengan baik. Skor rata-rata pada aspek keterampilan menggunakan alat laboratorium dan melakukan kerja yaitu 3,92. Pada rubrik keterampilan menggunakan alat laboratorium menunjukkan bahwa siswa dapat melakukan langkah kerja secara urut sesuai petunjuk. Namun dari hasil pengamatan masih dijumpai ada mahasiswa yang menggunakan alat laboratorium tidak sesuai dengan fungsinya. Aspek kedua yang dinilai adalah keterampilan mengamati. Keterampilan mengamati meliputi keterampilan menggunakan indera dan keterampilan mencari perbedaan atau persamaan dari praktikum yang dilakukan dengan praktikum pembuatan nata de coco. Proses pembuatan nata merupakan teknologi terapan yang diadopsi dari teknologi pembuatan nata de 
Dian Puspita Anggraini (1), Eva Nurul Malahayati (2). 2018. Penerapan Metode Praktikum Pembuatan Nata de Milk Pada Matakuliah Pengantar Bioteknologi di Program Studi Pendidikan Biologi Universitas Islam Balitar.

Konstruktivisme, 10 (1): 1-16

coco dengan mengganti air kelapa dengan whey sebagai media fermentasidengan menambahkan Acetobacter xylinum sebagai starter. Selama kegiatan pembelajaran ini mahasiswa dapat mengamati hasil praktikum pembuatan nata de milkdan membandingkannya dengan produk nata de coco. Mahasiswa diminta untuk mengisi formulir isian dengan memberikan S (sama) apabila terdapat persamaan dan huruf B (beda) bila tidak terdapat perbedaan kriteria diantara dua produk yang diuji. Kriteria penilaian yang digunakan adalah tektur, rasa, warna dan aroma nata de milk, kemudian seluruh penilaian mahasiswa tersebut ditabulasikan. Mahasiswa dapat mengamati perbedaan hasil nata tersebut dengan skor rata-rata 3,98.

Kegiatan mengukur hasil praktikum juga termasuk aspek yang dinilai dalam keterampilan proses. Kegiatan pengukuran dilakukan mahasiswa bersamaan dengan kegiatan pengamatan. Dalam pembelajaran ini mahasiswa dapat mengukur ketebalan nata yang mereka buat dengan menggunakan jangka sorong (Vernier Kapiler 150x0,05 MM/6"X1/128") pada tiga tepi yang memiliki ketebalan tertinggi dan terendah, kemudian dihitung ketebalan ratarata. Hal ini terbukti dengan perolehan skor rata-rata pada aspek ini yaitu 3,73 menunjukkan bahwa siswa mampu mengukur ketebalan nata dengan teliti, sungguh-sungguh dan benar sesuai dengan objek yang diukur dengan sedikit bantuan dosen. Selanjutnya yang dinilai dalam penelitian ini adalah keterampilan menyampaikan hasil praktikum dengan indikatormampu membaca dan mengkompilasi informasi dalam grafik atau diagram, menggambar data empiris dengan grafik, tabel atau diagram, menjelaskan hasil percobaan, menyusun dan menyampaikan laporan secara sistematis dan jelas (Rustaman et al. 2003). Dari hasil pengamatan siswa dapat menyampaikan hasil praktikum dengan skor rata-rata 3,82 yang menunjukkan bahwa siswa dapat menyampaikan hasil praktikum dengan benar dan mampu menggambarkan tabel atau grafik dengan jelas serta dapat menjelaskannya dengan tidak berbelit-belit.

Keterampilan merumuskan hipotesis merupakan keterampilan proses sains terpadu. Keterampilan merumuskan hipotesis menyatakan hubungan antara dua variabel, mengajukan perkiraan penyebab suatu hal terjadi dengan mengungkapkan bagaimana cara melakukan pemecahan masalah (Hartono, 2007). Rata-rata perolehan dalam menyusun hipotesis yaitu 3,56. Pada rubrik keterampilan proses menunjukkan bahwa siswa mampu menyusun hipotesis dengan benar namun masih memerlukan bantuan dosen. Hal ini sejalan dengan pendapat Rustaman et al. (2003) yang menyatakan bahwa 
Dian Puspita Anggraini (1), Eva Nurul Malahayati (2). 2018. Penerapan Metode Praktikum Pembuatan Nata de Milk Pada Matakuliah Pengantar Bioteknologi di Program Studi Pendidikan Biologi Universitas Islam Balitar.

Konstruktivisme, 10 (1): 1-16

keterampilan berhipotesis tidak mudah namun dosen harus memberikan kesempatan kepada mahasiswa untuk mengemukakan penjelasan pada kondisi spesifik berdasarkan gagasan yang ada yang akan menjadi dasar pengembangan keterampilan proses selanjutnya. Keterampilan proses sains menghimpun data percobaanyang merupakan kegiatan mengumpulkan data dari hasil pengamatan dan pengukuran. Skor rata-rata yang diperoleh pada keterampilan menghimpun data percobaan yaitu 3,78 yang menunjukkan bahwa mahasiswa menghimpun data hasil praktikum dalam diagram batang dan tabel pengamatan, ditulis dengan rapi, tulisan jelas, dan data ditulis sesuai dengan fakta. Selanjutnya keterampilan proses sains membuat kesimpulan merupakan kemampuan membuat suatu kesimpulan tentang suatu fenomena setelah mengumpulkan, menginterpretasi data dan informasi.Skor keterampilanproses sains membuat kesimpulan sebesar 3,46 menunjukkan bahwa siswa dapat membuat kesimpulan dengan benar namun masih menggunkan kalimat yang kurang efektif sehingga dosen perlu memberikan bimbingan.

Selain itu mahasiswa juga diberi tugas kelompok membuat laporan praktikum Nata de Milk. Pada rubrik keterampilan proses sains menunjukkan bahwa siswa mampu menyusun laporan secara sistematis sesuai petunjuk penulisan laporan dengan cukup lengkap dengan skor rata-rata 3,75. Dari hasil pengamatan masih terdapat beberapa kelompok yang tidak mencantumkan daftar pustaka pada laporan mereka sehingga penilaian laporan kurang sempurna. Berdasarkan hasil pengamatan penilaian keterampilan proses sains mencapai persentase ketuntasan klasikal sebesar $100 \%$ dengan kriteria baik dan baik sekali. Berdasarkan hasil observasi tersebut sudah sesuai dengan indikator keberhasilan yaitu $\geq 75 \%$ siswa mencapai keterampilan proses sains dengan kriteria baik.

Hasil pembelajaran dengan metode praktikum pembuatan Nata de Milksudah jelas bahwa mahasiswa dapat mengembangkan sejumlah keterampilan proses sains. Keterampilan proses sains dapat digunakan oleh mahasiswa untukbelajar proses dan sekaligus produk ilmu pengetahuan. Keterampilan proses sains memberikan kesempatan kepada mahasiswa untuk secara nyata bertindak sebagai seorang ilmuwan. Dari uraian di atas dapat diutarakan bahwa dengan menerapkan penilaian keterampilan proses sains, menuntut adanya keterlibatanfisik dan mental-intelektual mahasiswa. Hal ini dapat digunakan untuk melatih dan mengembangkan keterampilan intelektual atau kemampuan berfikir siswa. Selain itu juga mengembangkan sikap-sikap 
Dian Puspita Anggraini (1), Eva Nurul Malahayati (2). 2018. Penerapan Metode Praktikum Pembuatan Nata de Milk Pada Matakuliah Pengantar Bioteknologi di Program Studi Pendidikan Biologi Universitas Islam Balitar. Konstruktivisme, 10 (1): 1-16

ilmiah dan kemampuan siswa untukmenemukan dan mengembangkan fakta, konsep, dan prinsip ilmu ataupengetahuan. Selanjutnya dapat digunakan untuk menyelesaikan masalah- masalah (Funk, 1985 dalam Dimyati dan Mudjiono,2002).

\section{Hasil Belajar}

Hasil belajar siswa diperoleh dari laporan praktikum pembuatan Nata de Milkdan evaluasi. Rekapitulasi hasil belajar siswa dapat disajikan pada Tabel 4.

Tabel 4. Data Hasil Belajar Siswa

\begin{tabular}{clc}
\hline No & \multicolumn{1}{c}{ Variasi } & Data \\
\hline 1 & Jumlah Mahasiswa & 27 \\
\hline 2 & Nilai tertinggi & 87.52 \\
\hline 3 & Nilai terendah & 77.86 \\
\hline 4 & Rata-rata & 80.23 \\
\hline 5 & Ketuntasan Klasikal & $100 \%$ \\
\hline
\end{tabular}

Berdasarkan Tabel 4 dapat diketahui bahwa hasil belajar mahasiswa telah mencapai indikator keberhasilan yang ditentukan, yaitu ketuntasan klasikal $\geq 85 \%$. Nilai rata-rata kelas telah mencapai 80 . Sehingga secara keseluruhan mempunyai ketuntasan klasikal $100 \%$ karena tidak ada siswa yang memperoleh nilai di bawah KKM.

Keterlibatan mahasiswa secara langsung dalam pembelajaran berpengaruh pada hasil belajar siswa. Praktikum adalah salah satu bentuk kegiatan yang bertujuan untuk memantapkan pengetahuan siswa terhadap materi pelajaran melalui aplikasi, analisis, sintesis, dan evaluasi terhadap teori yang dilakukan di dalam laboratorium (Zainudin 1983). Menurut Winatapura (1993) metode praktikum adalah suatu cara penyajian yang disusun secara aktif untuk mengalami dan membuktikan sendiri tentang apa yang dipelajarinya.Melalui praktikum, mahasiswa dapat memiliki banyak pengalaman, baik berupa pengamatan langsung atau bahkan melakukan percobaan sendiri dengan objek tertentu. Praktikum pembuatan Nata de Milk dari limbah whey telah melibatkan mahasiswa secara langsung untuk mengolah limbah whey yang berlimpah menjadi produk yang lebih bernilai. Limbah whey 
Dian Puspita Anggraini (1), Eva Nurul Malahayati (2). 2018. Penerapan Metode Praktikum Pembuatan Nata de Milk Pada Matakuliah Pengantar Bioteknologi di Program Studi Pendidikan Biologi Universitas Islam Balitar.

Konstruktivisme, 10 (1): 1-16

yang digunakan merupakan limbah hasil pengolahan susu yang selama ini belum dimanfaatkan dengan baik.

Pembelajaran bioteknologi dengan praktikum pembuatan Nata de Milk merupakan prinsip pembelajaran sambil bekerja yang memberikan pengalaman langsung bagi mahasiswa. Pengalaman langsung merupakan pengalaman yang diperoleh mahasiswa sebagai hasil dari aktivitas mahasiswa sendiri. Mahasiswa mengalami, merasakan sendiri segala sesuatu yang berhubungan dengan objek yang dipelajarinya. Mahasiswa berhubungan langsung dengan objek yang hendak dipelajari tanpa menggunakan perantara.Tidak diragukan lagi bahwa melalui pengalaman langsung (first-hand experiences), mahasiswa dapat belajar lebih mudah dibandingkan dengan belajar melalui sumber sekunder, misalnya buku. Hal tersebut sangat sesuai dengan pendapat Bruner yang menyatakan bahwa anak belajar dengan pola inactive melalui perbuatan (learning by doing) akan dapat mentrasnfer ilmu pengetahuan yang dimilikinya pada berbagai situasi (Sastrawijaya, 1998).Sesuai dengan pendapat Sardiman (2007) menyatakan belajar melalui praktik atau mengalami secara langsung akan lebih efektif, mampu membina sikap, keterampilan, cara berfikir kritis dan lain-lain, bila dibandingkan dengan belajar hafalan saja.

\section{SIMPULAN DAN SARAN}

\section{Simpulan}

Berdasarkan hasil penelitian yang telah dilakukan maka dapat diambil kesimpulan sebagai berikut.

1. Pembelajaran dengan metode praktikum pembuatan Nata de Milkdapat diterapkan pada matakuliah pengantar bioteknologi yang ditunjukkan dengan tercapainya indikator keberhasilan keterampilan proses sains yaitu $\geq 75 \%$ dengan kriteria baik.

2. Pembelajaran dengan metode praktikum pembuatan Nata de Milk dapat diterapkan pada matakuliah pengantar bioteknologidengan indikator $\geq 85 \%$ mahasiswa memperoleh nilai hasil belajar $\geq 80$.

\section{Saran}

Berdasarkan hasil penelitian yang diperoleh dari penelitian ini, ada beberapa saran yang akan dikemukakan. 
Dian Puspita Anggraini (1), Eva Nurul Malahayati (2). 2018. Penerapan Metode Praktikum Pembuatan Nata de Milk Pada Matakuliah Pengantar Bioteknologi di Program Studi Pendidikan Biologi Universitas Islam Balitar. Konstruktivisme, 10 (1): 1-16

1. Perlu manajemen laboratorium yang baik terhadap pelaksanaan pembelajaran dengan metode praktikum sehingga mahasiswa mampu melaksanakan proses praktikum sesuai standar operasional prosedur laboratorium.

2. Pembelajaran dengan metode praktikum pembuatan Nata de Milk perlu dikembangkan pada objek lain yang memiliki permasalahan yang sama.

\section{DAFTAR RUJUKAN}

Arikunto S. 2006. Prosedur Penelitian Suatu Pendekatan Praktek. Jakarta: Rineka Cipta.

Dimyati dan Mudjiono. 2002. Belajar dan Pembelajaran. Jakarta: Rineka Cipta dan Depdikbud.

Idris. 2003. Analisa Gizi Whey. http://wordpress.com Analisa Gizi Idris. Diakses tanggal 2 Februari 2009

Jenie, B.S.L dan W.P. Rahayu. 1993. Penanganan Limbah Industri Pangan. Penerbit Kanisius. Yokyakarta

Palungkun, R. 1993. Aneka Produk Olahan Kelapa. Penebar Swadaya. Jakarta

Rustaman N Y, S Dirdjosoemarto, Y Achmad, R Subekti, M Nurjhani. 2003. Strategi Belajar Mengajar Biologi. Bandung: Universitas Pendidikan Indonesia.

Sagala, S. 2005. Konsep dan Makna Pembelajaran. Bandung: CV. Alfabeta.

Sanjaya W. 2007. Strategi Pembelajaran. Jakarta: Kencana.

Sardiman. 2007. Interaksi dan Motivasi Belajar Mengajar. Jakarta: PT Raja Grafindo Persada.

Sastrawijaya, Tresna. 1998. Proses Belajar Mengajar Kimia. Jakarta : Depdikbud, Dirjendikti, Proyek Pengembangan Lembaga Pendidikan Tenaga Kependidikan.

Subiantoro, A.W. 2010. Pentingnya Praktikum dalam Pembelajaran IPA (Makalah). Yogyakarta: Universitas Negeri Yogyakarta. 
Dian Puspita Anggraini (1), Eva Nurul Malahayati (2). 2018. Penerapan Metode Praktikum Pembuatan Nata de Milk Pada Matakuliah Pengantar Bioteknologi di Program Studi Pendidikan Biologi Universitas Islam Balitar. Konstruktivisme, 10 (1): 1-16

Widodo. 2003. Bioteknologi Industri Susu. Lactasia Press. Yokyakarta

Winatapura, Udin. 1993. Strategi Belajar Mengajar IPA. Jakarta: Departemen Pendidikan dan Kebudayaan.

Zainudin. 1983. Pusat Sumber Belajar. Jakarta: Departemen Pendidikan dan Kebudayaan. 